\title{
Body Position Code
}

National Cancer Institute

\section{Source}

National Cancer Institute. Body Position Code. NCI Thesaurus. Code C93521.

A coded value specifying the 3-dimensional spatial orientation of an entity. 